\title{
Implementasi Model Number Head Together Terhadap Hasil Belajar Siswa Kelas IV SD pada Materi Faktor Pesekutuan Besar dan Kelipatan Persekutuan Kecil
}

\author{
${ }^{*}$ Dewi Lestari ${ }^{1}$, Rahmat Sudrajat ${ }^{2}$, M. Yusuf Setia W ${ }^{3}$
}

${ }^{123}$ Fakultas Ilmu Pendidikan, Universitas PGRI Semarang

\author{
A R T I C L E I N F O \\ Article history: \\ Received 15 August 2019 \\ Received in revised form \\ 20 September 2019 \\ Accepted 10 October 2019 \\ Available online 27 \\ November 2019 \\ Kata Kunci: \\ hasil belajar, number head \\ together \\ Keywords: \\ student learning outcomes, \\ number head together \\ model
} menggunakan model pembelajaran Number Head Together terhadap hasil belajar siswa pada mata pelajaran matematika materi FPB dan KPK kelas IV SDN Kaligawe, indonesia yaitu, hasil belajar siswa lebih meningkat.

A B S T R A C T

This research aims at increasing students' interest in learning mathematics in FPB and KPK material by using the Number Head Together model. This research was a quantitative with a pre-experimental research design with a non-equivalent pre-test post-test control group design. The subjects used were all students of class IVA and class IVB of elementary school which was on IVA students consisted of 28 students and IVB students consisted of 28 students by using saturated sampling techniques. Data collection techniques with tests, observations, and documentation. The results showed the average score of the pretest in the control class was 50.54 and the average score of the pretest in the experimental class was 50.00. While the results of the average posttest in the control group was 69.11 and the average score on posttest in the experimental class was 76,42. This was evidenced by the results of the $\mathrm{t}$-test in which the number of $\mathrm{t}$-count $>\mathrm{t}$-table $(2.093>2.021)$. So that there was a significant effect on students' learning outcomes by using the Number Head Together learning model on student learning outcomes in mathematics subject matter FPB and KPK on grade IV elementary students learning outcomes. equivalent control group pre-test post-test design. Subjek yang

\begin{abstract}
A B S T R A K pelajaran matematika materi FPB dan KPK dengan menggunakan
model Number Head Together. Penelitian ini merupakan penelitian digunakan adalah seluruh siswa kelas IV A dan kelas IV B SDN 28 dan siswa kelas IV B berjumlah 28 dengan menggunakan teknik
sampling jenuh. Teknik pengumpulan data dengan tes, observasi, dan dokumentasi. Hasil penelitian menunjukkan nilai rata-rata pretest pada kelas kontrol 50,54 dan nilai rata-rata pretest pada kelas eksperimen
50,00 . Sedangkan hasil nilai rata-rata posttest pada kelas kontrol 69,11 dan hasil nilai rata-rata posttest pada kelas eksperimen 76,42 . Hal tersebut dibuktikan dengan hasil uji t dimana jumlah thitung $>$ tabel $(2,093>$ (1)
\end{abstract}

\section{Pendahuluan}

Pendidikan merupakan segala situasi hidup yang mempengaruhi pertumbuhan individu sebagai pengalaman belajar yang berlangsung dalam segala lingkungan dan sepanjang hayat (Astuti, 2015). Undang-undang No. 20 Tahun 2003 tentang Sistem Pendidikan Nasional menyatakan bahwa "Pendidikan adalah usaha sadar dan terencana untuk mewujudkan suasana belajar dan proses pembelajaran agar siswa secara aktif mengembangkan potensi dirinya untuk memiliki kekuatan spiritual keagamaan pengendalian diri, kepribadian, akhlak yang mulia, serta keterampilan yang diperlukan dirinya, masyarakat, bangsa dan Negara". 
Negara Indonesia sangat membutuhkan Sumber Daya Manusia (SDM) yang berkualitas untuk membangun dan mengembangkan potensi yang dimiliki oleh negara Indonesia agar tidak banyak dikuasai oleh negara asing, upaya untuk mengembangkan Sumber Daya Manusia dapat dilakukan melalui pendidikan, sebagaimana garis besar dari tujuan pendidikan itu sendiri yaitu untuk membantu siswa mengembangkan potensi yang ada pada dirinya ke arah yang lebih positif sehingga seseorang dapat menjadi lebih bermoral serta bermanfaat bagi dirinya sendiri maupun lingkungannya, sebagaimana pengertian pendidikan dalam Undang-Undang nomor 20 tahun 2003 pasal 1 yang berbunyi: Pendidikan adalah usaha sadar dan terencana untuk mewujudkan suasana belajar dan proses pembelajaran agar siswa secara aktif mengembangkan potensi dirinya untuk memiliki kekuatan spiritual keagamaan, pengendalian diri, kepribadian, kecerdasan, akhlak mulia, serta keterampilan yang diperlukan dirinya, masyarakat, bangsa dan negara. Karena pendidikan merupakan usaha secara sadar dan terencana maka dalam pengaplikasiaanya harus direncanakan dengan sebaik mungkin agar tujuan yang hendak dicapai dapat tercapai dengan maksimal, pendidikan menurut (Muhibbin Syah, 2012)"pendidikan dapat diartikan sebagai sebuah proses dengan metode-metode tertentu sehingga orang memperoleh pengetahuan, pemahaman dan cara bertingkah laku yang sesuai dengan kebutuhan" (Ichsan, 2016).

Menurut (Amir, 2014), Matematika merupakan disiplin ilmu yang bersifat khas dibandingkan dengan disiplin ilmu yang lain. Dapat dikatakan bahwa matematika berkenaan dengan konsep-konsep abstrak yang tersusun secara hirarkis dan penalarannya bersifat deduktif. Hal yang demikian tentu akan membawa akibat pada terjadinya proses pembelajaran matematika. Menurut Umar (2012) mengemukakan bahwa "kemampuan komunikasi matematis (mathematical communication) dalam pembelajaran matematika sangat perlu untuk dikembangkan, hal ini karena melalui komunikasi siswa dapat mengorganisasikan berpikir matematisnya baik secara lisan maupun tulisan".

Pembelajaran matematika adalah proses pemberian pengalaman belajar kepada peserta didik melalui serangkaian kegiatan yang terencana sehingga peserta didik memperoleh pengetahuan tentang matematika yang dipelajari, cerdas, terampil, mampu memahami dengan baik bahan yang diajarkan. Menurut (Rifaldiyah, 2019)Manfaat matematika adalah membekali peserta didik dengan kemampuan berpikir logis, analitis, sistematis, kritis, dan kreatif, serta kemampuan bekerjasama. Maka dari itu dalam pembelajaran matematika, keberhasilan suatu pengajaran dipengaruhi oleh faktor yang terangkum dalam sistem pengajaran yaitu penggunaan model/metode pembelajaran yang sesuai dengan perkembangan dan kemampuan siswa, sehingga tercapai tujuan pengajaran secara optimal.

Berdasarkan hasil observasi pada tanggal 10 April 2019 dengan guru kelas IV Anita Esti Utami, S.Pd dan kepala sekolah Ibu Tri Lestari, S.Pd di SD Kaligawe Kota Semarang. Bahwa jumlah siswa kelas IV A sebanyak 28 siswa, dengan rician 15 siswa perempuan dan 13 siswa laki-laki. Nilai KKM yang ditetapkan untuk mata pelajaran matematika kelas IV adalah 70. Nilai rata-rata kelas yang diperoleh pada saat ulangan harian adalah 65 dengan nilai tertinggi 85 dan nilai terendah 40. Dari hasil nilai yang diperoleh siswa, peneliti melakukan observasi pada kegiatan belajar siswa dan diperoleh beberapa permasalahan antara lain masih kurang aktifnya siswa saat pembelajaran dan masih ada nilai siswa yang belum tuntas KKM pada pelajaran matematika. Dari hasil ulangan harian mata pelajaran matematika masih terdapat $60,7 \%$ siawa belum mampu memenuhi kriteria ketuntasan minimal (KKM).

Saat pelajaran matematika siswa terkesan kesulitan dalam memahami materi, memecahkan suatu masalah dan takut jika di minta guru untuk mencoba ke depan. Selain itu masih ditemui dalam proses belajar mengajar guru masih menggunakan model pembelajaran konvensional biasanya hasil belajar siswa masih rendah. Hasil belajar merupakan kemampuan yang diperoleh individu setelah proses belajar berlangsung, yang dapat memberikan perubahan tingkah laku baik pengetahuan, pemahaman, sikap dan keterampilan siswa sehingga menjadi lebih baik dari sebelumnya Solihin (2012). Pada pembelajaran matematika kelas IV materi faktor persekutuan besar (FPB) dan kelipatan persekutuan kecil (KPK) siswa merasa kesulitan dalam memahami materi dan memecahkan masalah, kurangnya keinginan dalam mencoba secara individu maupun maju mengerjakan di papan tulis, serta belum menggunakan model yang mudah di gunakan untuk memahami materi yang sesuai dengan situasi dan kondisi di dalam kelas.

Dari rendahnya hasil belajar tersebut model pembelajaran menjadi bagian penting yang harus mendapat perhatian lebih dari guru. Salah satu solusi untuk meningkatkan keberhasilan belajar siswa, yaitu dengan menggunakan pembelajaran aktif di mana siswa melakukan sebagian besar pekerjaan yang harus dilakukan baik secara individu atau kelompok. Hal tersebut dapat diatasi dengan menggunakan pembelajaran kooperatif.

Model pembelajaran Numbered Heads Togather merupakan salah satu tipe model dalam pembelajaran kooperatif. Suherman (Jumrawarsi, 2017) menyatakan bahwa pembelajaran kooperatif mencangkup suatu sekelompok kecil siswa yang bekerja sebagai sebuah tim untuk menyelesaikan masalah, menyelesaikan tugas, atau mengerjakan sesuatu untuk mencapai tujuan bersama. Numbered 
Heads Togather salah satu model pembelajaran yang berorientasi pada siswa, yakni dengan melakukan pembelajaran secara berkelompok dan berpusat pada siswa (Drayatun \& Rahmawati, 2017). Menurut Nurhadi dalam Malawati (2012) kelebihan model pembelajaran tipe NHT yaitu: Setiap siswa menjadi siap semua, Dapat berdiskusi dengan sungguh-sungguh, Siswa pandai dapat mengajarkan siswa yang kurang pandai, Penerimaan terhadap individu, Pemahaman yang lebih mendalam, Sikap apatis berkurang. Sedangkan kelemahannya adalah sebagai berikut: Kemungkinan memanggil nomor yang sama, Tidak semua anggota kelompok dipanggil oleh guru, Kekhawatiran terjadi kekacauan di kelas, Kekhawatiran siswa tidak dapat membagi tugas dengan adil.

Model pembelajaran ini diterapkan dengan desain khusus yang berbeda dengan model sebelumnya dan dari model yang telah digunakan, dan memiliki langkah-langkah yang menarik, membuat siswa aktif. Keaktifan siswa dilihat dari cara siswa mengikuti petunjuk yang diminta guru dengan baik dan sesuai. Siswa akan meningkat hasil belajarnya dengan variasi penggunaan model pembelajaran yang menarik sehingga dalam pemecahan masalah maupun soal dapat terselesaikan dengan mudah.

Berdasarkan uraian di atas, maka penulis melakukan penelitian mengenai keefektifan model pada mata pelajaran matematika. Oleh karena itu dalam penelitian ini peneliti memfokuskan penelitian dengan judul "Keefektifan Model Number Head Together Terhadap Hasil Belajar Siswa Pada Mata Pelajaran Matematika Materi Faktor Persekutuan Besar dan Kelipatan Persekutuan Kecil. (Studi Deskriptif di Kelas IV SDN Kaligawe Semarang)".

\section{Metode}

Penelitian yang dilakukan merupakan penelitian kuantitatif. (Sugiyono, 2017) Metode penelitian kuantitatif adalah metode penelitian yang berlandaskan pada filsafat positivisme, digunakan untuk meneliti pada populasi atau sampel tertentu, teknik pengambilan sampel pada umumnya dilakukan secara random, pengumpulan data menggunakan instrumen penelitian analisis data bersifat kuantitatif/statistic dengan tujuan untuk menguji, hipotesis yang telah ditetapkan. Metode yang digunakan dalam penelitian ini adalah metode Eksperimen kuasi. Desain yang digunakan dalam penelitian ini adalah non-equivalent control group pre-test post-test design (Sugiyono, 2017). Dalam desain ini kedua kelompok dipilih secara random. Dengan desain ini sampel dibagi menjadi 2 kelompok yaitu satu kelompok dengan eksperimen dan satu kelompok lagi dengan kelompok kontrol.

Teknik pengumpulan data dalam penelitian ini bertujuan untuk memperoleh data yang relevan, akurat, dan reliable. Yang dilakukan peneliti diantaranya tes, observasi, dokumentasi. Teknik tes digunakan untuk memperoleh data hasil belajar matematika materi FPB dan KPK siswa kelas IV SDN Kaligawe Kota Semarang. Observasi dalam penelitian ini untuk mengumpulkan data yang dapat dilakukan saat kegiatan proses belajar mengajar berlangsung seperti guru sedang belajar dan siswa saat belajar.

\section{Hasil dan Pembahasan}

Pada Berdasarkan hasil pre-test dan post-test baik dalam kelas kontrol maupun kelas eksperimen dapat diketahui bahwa terdapat nilai tertinggi, nilai terendah, dan nilai rata-rata hasil penelitian pre-test dan post-test. Deskripsi data pre-test dan post-test siswa dengan model konvensional dalam kelas kontrol dapat dilihat pada Tabel 1 berikut.

Tabel 1. Deskripsi Nilai Rata-rata Pretest dan Posttest dengan Model Konvensional dalam Kelas Kontrol

\begin{tabular}{cccc}
\hline Jenis Tes & NilaiTertinggi & Nilai Terendah & Rata-rata \\
\hline Pre-test & 70 & 25 & 50,54 \\
Post-test & 80 & 50 & 69,1 \\
\hline
\end{tabular}

Dari Tabel 1, rata-rata nilai hasil belajar pretest atau sebelum diberi perlakuan adalah 50,54 dengan 10 atau $35,7 \%$ siswa yang dinyatakan tuntas dan 18 atau $64,2 \%$ siswa yang dinyatakan tidak tuntas. Setelah diberi perlakuan menggunakan model pembelajaran konvensional dalam pembelajaran matematika FPB dan KPK rata-rata hasil belajar nilai rata-rata posttest adalah 69,1 dengan 17 atau 60,7\% siswa yang dinyatakan tuntas.

Deskripsi data pre-test dan post-test siswa dengan model Number Head Together dalam kelas eksperimen dapat dilihat pada Tabel 2 berikut. 
Tabel 2. Deskripsi Nilai Rata-rata Pretest dan Posttest dengan Model Number Head Together dalam Kelas Eksperimen

\begin{tabular}{cccc}
\hline Jenis Tes & NilaiTertinggi & Nilai Terendah & Rata-rata \\
Pre-test & 70 & 30 & 50 \\
Post-test & 100 & 50 & 76,42 \\
\hline
\end{tabular}

Dari Tabel 2, rata-rata nilai hasil belajar pretest atau sebelum diberi perlakuan adalah 50 dengan 7 atau 25\% siswa yang dinyatakan tuntas dan 21 atau $75 \%$ siswa yang dinyatakan tidak tuntas. Setelah diberi perlakuan berupa penggunaan model pembelajaran Number Head Together rata-rata hasil belajar nilai rata-rata posttest adalah 76,42 dengan 21 atau 75\% siswa yang dinyatakan tuntas.

Tabel 3. Deskripsi Hasil Nilai Siswa Posttest Pada Kelas Kontrol dan Kelas Eksperimen

\begin{tabular}{cccc}
\hline Kelas & NilaiTertinggi & Nilai Terendah & Rata-rata \\
\hline Kontrol & 80 & 50 & 69,11 \\
Eksperimen & 100 & 50 & 76,42 \\
\hline
\end{tabular}

Dari Tabel 3, hasil belajar posttest pada kelas kontrol nilai tertinggi 80 dan nilai terendahnya 50 dengan nilai rata-rata 69,11, sedangkan hasil belajar pada kelas eksperimen nilai tertinggi 100 dan terendahnya 50. Dimana peningkatan hasil belajar siswa pada kelas eksperimen lebih tinggi dibanding peningkatan hasil belajar siswa kelas kontrol.

Uji normalitas awal digunakan untuk mengetahui normal tidaknya data awal dari nilai pretest pada siswa kelas IV SDN Kaligawe. Data berdistribusi normal apabila Lo < Label. Adapun perhitungan normalitas pada siswa kelas IV B sebagai kelas kontrol dapat dilihat pada tabel 4 di bawah ini.

Tabel 4. Daftar Uji Normalitas Nilai Pre-Test dalam Kelas Kontrol

\begin{tabular}{cccc}
\hline Nilai & L $_{0}$ & Ltabel & Keterangan \\
\hline Pretest & 0,1383 & 0,173 & Data Berdistribusi Normal \\
\hline
\end{tabular}

Berdasarkan Tabel 4 diatas diperoleh hasil perhitungan dari nilai $\mathrm{L}_{0}=0,1383$ dengan $\mathrm{n}=28$ dengan taraf signifikan $5 \%$ didapat $\mathrm{L}_{\text {tabel }}=0,173$ dengan diperoleh $\mathrm{L}_{0}<\mathrm{Ltabel}$ atau $(0,1383<0,173)$ maka $\mathrm{H}_{\mathrm{a}}$ diterima, sehingga sampel berasal dari populasi berdistribusi normal.

Adapun perhitungan normalitas pada siswa kelas IV A sebagai kelas eksperimen dapat dilihat pada tabel 5 di bawah ini.

Tabel 5. Daftar Uji Normalitas Nilai Pre-Test dalam Kelas Eksperimen

\begin{tabular}{cccc}
\hline Nilai & $\mathrm{L}_{0}$ & Ltabel & Keterangan \\
\hline Pretest & 0,1612 & 0,173 & Data Berdistribusi Normal \\
\hline
\end{tabular}

Berdasarkan Tabel 5 diatas diperoleh hasil perhitungan dari nilai $\mathrm{L}_{0}=0,1612$ dengan $\mathrm{n}=28$ dengan taraf signifikan $5 \%$ didapat $\mathrm{L}_{\text {tabel }}=0,173$ dengan diperoleh $\mathrm{L}_{0}<\mathrm{L}_{\text {tabel }}$ atau $(0,1612<0,173) \mathrm{maka}_{\mathrm{a}}$ diterima, sehingga sampel berasal dari populasi berdistribusi normal.

Uji homogenitas hasil belajar sebelum perlakuan kelas eksperimen dan kelas kontrol dapat dilihat pada Tabel 6

Tabel 6. Uji Homogenitas Sebelum Perlakuan Kelas Eksperimen dan Kelas Kontrol

\begin{tabular}{llccc}
\hline Kelompok & $\mathrm{N}$ & Fhitung & Ftabel & Keterangan \\
Eksperimen & 28 & 1,14 & 2,12 & Homogen \\
Kontrol & 28 & & & \\
\hline
\end{tabular}

Berdasarkan tabel 6, diketahui hasil $F_{\text {hitung }}=1,14$ dan $F_{\text {tabel }}=2,12$. Dengan perhitungan uji homogenitas dari data awal kelas eksperimen dan kelas kontrol, diperoleh varians kelas eksperimen = 244,44 dan kelas kontrol $=278,41$ maka diperoleh nilai $F_{h i t u n g}=1,14$. Berdasarkan daftar tabel diperoleh nilai $\mathrm{F}_{\text {tabel }}=2,12$ dengan $\mathrm{dk}$ pembilang 27, dk penyebut 27 dan taraf signifikan 5\%. Dari perhitungan tersebut maka $F_{\text {hitung }}<F_{\text {tabel }}$ yaitu $1,14<2,12$ sehingga Ho diterima. Kesimpulan yang diperoleh dari uji 
homogenitas awal pada kelas eksperimen dan kelas kontrol adalah bahwa kedua kelompok tersebut berasal dari sampel yang homogen. Uji homogenitas hasil belajar sebelum perlakuan kelas eksperimen dan kelas kontrol dapat dilihat pada Tabel 7.

Tabel 7. Uji Homogenitas Setelah Perlakuan Kelas Eksperimen dan Kelas Kontrol

\begin{tabular}{lllll}
\hline Kelompok & $\mathrm{N}$ & Fhitung & Ftabel & Keterangan \\
Eksperimen & 28 & 1,91 & 2,12 & Homogen \\
Kontrol & 28 & & & \\
\hline
\end{tabular}

Berdasarkan Tabel 7, diketahui hasil $F_{\text {hitung }}=1,91$ dan $F_{\text {tabel }}=2,12$. Dengan perhitungan uji homogenitas dari data akhir kelas eksperimen dan kelas kontrol, diperoleh varians kelas eksperimen $=$ 233,07 dan kelas kontrol $=122,32$ maka diperoleh nilai $F_{\text {hitung }}=1,91$. Berdasarkan daftar tabel diperoleh nilai $\mathrm{F}_{\text {tabel }}=2,12$ dengan $\mathrm{dk}$ pembilang 27, dk penyebut 27 dan taraf signifikan 5\%. Dari perhitungan tersebut maka $F_{\text {hitung }}<F_{\text {tabel }}$ yaitu $0,191<2,12$ sehingga Ho diterima. Kesimpulan yang diperoleh dari uji homogenitas akhir pada kelas eksperimen dan kelas kontrol adalah bahwa kedua kelompok tersebut berasal dari sampel yang homogen.

Uji normalitas akhir digunakan untuk mengetahui normal tidaknya data akhir dari nilai posttest pada siswa kelas IV Kaligawe. Data berdistribusi normal apabila $\mathrm{L}_{0}<\mathrm{L}_{\text {tabel. }}$ Adapun perhitungan normalitas siswa kelas IV B sebagai kelas kontrol dapat dilihat pada tabel 8 di bawah ini.

Tabel 8. Daftar Uji Normalitas Nilai Post-Test dalam kelas control

\begin{tabular}{|c|c|c|c|}
\hline Nilai & Lo & Ltabel & Keterangan \\
\hline Prost-test & 0,1662 & 0,173 & Data Berdistribusi Normal \\
\hline
\end{tabular}

Berdasarkan Tabel 8 diatas diperoleh hasil perhitungan dari nilai $\mathrm{L}_{0}=0,1662$ dengan $\mathrm{n}=28$ dengan taraf signifikan $5 \%$ didapat $\mathrm{L}_{\text {tabel }}=0,173$ dengan diperoleh $\mathrm{L}_{0}<\mathrm{L}_{\text {tabel }}$ atau $(0,1662<0,173)$ maka $\mathrm{H}_{\mathrm{a}}$ diterima, sehingga sampel berasal dari populasi berdistribusi normal. Adapun perhitungan normalitas pada siswa kelas IV A sebagai kelas eksperimen dapat dilihat pada tabel 9 di bawah ini.

Tabel 9. Daftar Uji Normalitas Nilai Post-Test dalam kelas eksperimen

\begin{tabular}{cccc}
\hline Nilai & $\mathrm{L}_{0}$ & Ltabel & Keterangan \\
Prost-test & 0,1246 & 0,173 & Data Berdistribusi Normal \\
\hline
\end{tabular}

Berdasarkan Tabel 9 diatas diperoleh hasil perhitungan dari nilai $\mathrm{L}_{0}=0,1246$ dengan $\mathrm{n}=28$ dengan taraf signifikan $5 \%$ didapat $\mathrm{L}_{\text {tabel }}=0,173$ dengan diperoleh $\mathrm{L}_{0}<\mathrm{L}_{\text {tabel }}$ atau $(0,1246<0,173)$ maka $\mathrm{H}_{\mathrm{a}}$ diterima, sehingga sampel berasal dari populasi berdistribusi normal.

Hasil belajar kelas kontrol dan kelas eksperimen selanjutnya dibandingkan dengan menggunakan uji-t yang bertujuan untuk ada tidaknya peningkatan hasil belajar siswa sebelem dan sesudah diberi perlakuan dengan menggunakan model Number Head Together.

Tabel 10. Hasi Perhitungan Uji-t Hasil Belajar Siswa

\begin{tabular}{|c|c|c|c|c|c|}
\hline Subjek & Kelas & thitung & tabel & Kriteria & Keterangan \\
\hline Kelas IV A dan B & Eksperimen & & & & \\
\hline SDN Kaligawe & Kontrol & 2,093 & 2,021 & $t_{\text {hitung }}>t_{\text {tabel }}$ & Ho diterima \\
\hline
\end{tabular}

Berdasarkan analisis data hasil belajar tabel 10. Berdasarkan ttabel dengan $\mathrm{dk}=\mathrm{n} 1+\mathrm{n} 2-2=28+$ $28-2=54, \alpha 5 \%$ yaitu 2,021 Dari perhitungan di peroleh thitung = 2,093, $\mathrm{t}$ hitung $>\mathrm{t}$ tabel $(2,093>2,021)$ maka hal ini menunjukan bahwa uji t hasil belajar signifikan. sehingga H0 ditolak artinya Hasil belajar siswa pada Pembelajaran Number Head Together lebih baik dibandingkan hasil belajar siswa konvensional.

Pembahasan ini berisi tentang hasil penelitian yang dilakukan pada siswa kelas IV SDN Kaligawe, Semarang dengan menggunakan dua kelas pada pelajaran matematika materi FPB dan KPK. Satu kelas 
sebagai kelas kontrol dan satu kelas sebagai kelas eksperimen. Pada kelas kontrol tidak diberi perlakuan sedangkan di kelas eksperimen diberi perlakuan berupa model pembelajaran Number Head Together. Penelitian ini bertujuan untuk mengetahui keefektifan model Number Head Together terhadap hasil belajar siswa pada mata pelajaran matematika materi faktor persekutuan besar dan kelipatan persekutuan kecil. (studi deskriptif di kelas IV SDN Kaligawe Semarang).

Setelah proses pembelajaran dilaksanakan pada kelas eksperimen dengan perlakuan menggunakan model Number Head Together dan kelas kontrol yang diberi perlakuan dengan model konvensional, menunjukkan adanya keefektifan hasil belajar siswa pada kelas eksperimen dan kelas kontrol. Rata-rata nilai akhir (Posttest) hasil belajar siswa kelas eksperimen diperoleh rata-rata 76,43 dan rata-rata nilai akhir (Posttest) hasil belajar siswa kelas kontrol sebesar 69,10. Berdasarkan hasil analisis akhir yang telah dilakukan dengan uji normalitas dan uji homogenitas menunjukan bahwa kedua sampel berasal dari populasi yang berdistribusi normal dan homogen, sehingga dilakukan uji $t$, diperoleh hasil $t_{\text {hitung }}$ sebesar 2,093 dengan $t_{\text {tabel }} 2,021$. Karena $t_{\text {hitung }}>t_{\text {tabel }}(2,093>2,021)$, Sehingga Ho ditolak artinya hasil belajar siswa pada pembelajaran Number Head Together lebih baik dibandingkan hasil belajar siswa konvensional.

Hasil temuan didukung oleh pendapat Hamdayama (2014 : 177) bahwa model pembelajaran Number Head Together ini merupakan model pembelajaran yang dapat melatih siswa untuk dapat bekerja sama dan menghargai pendapat orang lain, melatih siswa untuk bisa menjadi tutor sebaya, memupuk rasa kebersamaan, membuat siswa menjadi terbiasa dengan perbedaan, dapat melakukan diskusi dengan sungguh-sungguh, dan tidak ada siswa yang mendominasi dalam kelompok karena ada nomor yang membatasi.

Langkah terakhir yang dilakukan oleh peneliti adalah menghitung ketuntasan belajar individu dan ketuntasan belajar klasikal yang diharapkan. Untuk ketuntasan belajar klasikal dapat dihitung menggunakan rumus dan diperoleh ketuntasan belajar klasikal pretest pada kelas kontrol $=28,57 \%$ dan pada kelas eksperimen diperoleh ketuntasan belajar klasikal pretest $=25 \%$. Kemudian untuk ketuntasan belajar klasikan posttest pada kelas eksperimen dengan menggunakan model Number Head Together diperoleh hasil 75\% dan pada kelas kontrol dengan menggunakan model konvensional diperoleh hasil $60,71 \%$. Berdasarkan hasil diatas, dapat disimpulkan bahwa penggunaan model pembelajaran Number Head Together dapat meningkatkan hasil belajar matematika materi FPB dan KPK kelas IV SDN Kaligawe.

Hal ini sejalan dengan (Sari et al., 2017)menyatakan bahwa, adanya pengaruh yang signifikan yaitu meningkatnya hasil belajar matematika kelas III dengan model pembelajaran Number Head Together berbantu permainan tradisional engklek. Sejalan dengan (Khaeruman, Ratna Azizah, 2018) menyatakan bahwa, adanya pengaruh yang signifikan terhadap hasil belajar siswa pada materi matematika tema 2 subtema 4 materi pembagian tiga bilangan kelas II dengan menggunakan model Number Head Together. Penelitian ini sejalan dengan hasil penelitian Maheady, dkk. (2006) tentang keunggulan model pembelajaran kooperatif tipe Numbered Heads Together saat diterapkan dalam kegiatan pembelajaran yang menyimpulkan bahwa model pembelajaran Numbered Heads Together merupakan teknik pengajaran yang paling efisien dan paling efektif untuk meningkatkan respon siswa dan memperbaiki prestasi.

Penelitian ini sejalan dengan hasil penelitian yang dilakukan oleh Lyly Kusdartiana NB, dkk. (2013) tentang keefektifan model pembelajaran kooperatif tipe Numbered Heads Together saat diterapkan dalam kegiatan pembelajaran dan menyimpulkan bahwa pembelajaran kooperatif tipe NHT efektif diterapkan untuk meningkatkan aktivitas dan hasil belajar siswa. Penelitian ini sejalan dengan penelitian yang dilakukan oleh Erlangga Putra, dkk. (2012) tentang keunggulan model pembelajaran kooperatif tipe Numbered Heads Together yang menyimpulkan bahwa hasil belajar matematika siswa yang menggunakan model pembelajaran kooperatif tipe Numbered Heads Together (NHT) disertai LKS berbasis Kontekstual lebih baik daripada hasil yang menggunakan pembelajaran konvensional.

Penelitian ini meneliti tentang keaktifan belajar siswa dan sejalan dengan penelitian yang dilakukan oleh Muhammad Sidiq (2012) tetapi berbeda dalam penerapan model pembelajaran yang dipakai dalam penelitian. Dalam penelitian Muhammad Sidiq (2012) yang berkaitan dengan keaktifan belajar siswa menyimpulkan melalui penerapan model Participative Teaching and Learning dapat meningkatkan keaktifan belajar matematika siswa pada pokok bahasan bangun datar (segiempat). Penelitian ini sejalan dengan hasil penelitian oleh Octarina Hidayatus Sholikhah, dkk. (2014) tentang keunggulan model pembelajaran kooperatif tipe Numbered Heads Together yang menyimpulkan bahwa prestasi belajar siswa dengan model pembelajaran NHT lebih baik daripada GI maupun langsung. Penelitian ini menyimpulkan keunggulan model pembelajaran kooperatif tipe Numbered Heads Together dalam meningkatkan keaktifan belajar matematika siswa. 


\section{Simpulan dan Saran}

Dari Model Pembelajaran Number Head Together efektif terhadap hasil belajar siswa mata pelajaran matematika materi FPB dan KPK kelas IV SDN Kaligawe. Hal tersebut dapat dibuktikan dengan diperolehnya nilai pretest pada kelas kontrol dengan rata-rata nilai 50,54 dengan ketuntasan 28,57\% atau 8 siswa dinyatakan tuntas, dan 71,43\% atau 20 siswa yang dinyatakan tidak tuntas dan perolehan nilai pretest pada kelas eksperimen dengan rata-rata nilai 50,00 dengan ketuntasan 25\% atau 7 siswa dinyatakan tuntas, dan $75 \%$ atau 21 siswa yang dinyatakan tidak tuntas. Sedangkan hasil posttest pada kelas kontrol dengan rata-rata 69,11 dengan 17 atau 60,71 siswa yang dinyatakan tuntas, dan 11 atau $39,29 \%$ siswa yang dinyatakan tidak tuntas dan hasil posttest pada kelas eksperimen dengan rata-rata 76,43 dengan 21 atau 75\% siswa yang dinyatakan tuntas, dan 7 atau 25\% siswa yang dinyatakan tidak tuntas. Dari perhitungan hasil uji t menunjukkan bahwa $t_{\text {hitung }}>t_{\text {tabel }}(2,093>2,021)$ maka Ho ditolak sehingga uji t hasil belajar signifikan. Dapat disimpulkan terdapat keefektifan yang signifikan terhadap hasil belajar siswa dengan menggunakan model pembelajara Number Head Together terhadap hasil belajar siswa pada mata pelajaran matematika materi FPB dan KPK kelas IV SDN Kaligawe yaitu, hasil belajar siswa lebih meningkat.

\section{Daftar Rujukan}

Abdul, Solihin. 2012. Analisis Kebijakan. Jakarta: Bumi Aksara

Amir, A. (2014). Pembelajaran Matematika SD dengan Menggunakan Media Manipulatif. Forum Paedagogik, VI(01), 72-89.

Astuti, A. (2015). Peran Kemampuan Komunikasi Matematika Terhadap Prestasi Belajar Matematika Siswa. Jurnal Formatif, 2(2), 102-110.

Depdiknas .2003. Undang-undang RI No.20 tahun 2003.tentang sistem pendidikan nasional.

Drayatun, S., \& Rahmawati, A. (2017). Penerapan Model Pembelajaran Kooperatif Tipe Tgt Untuk Meningkatkan Aktivitas Dan Motivasi Belajar Siswa Kelas Viid Smp Negeri 1 Kokop. Jurnal Pena Sains, 4(1).

Hamdayama, Jumanta. 2014. Model dan Metode Pembelajaran Kreatif. Jakarta: Ghalia Indonesia.

Haydon, T dkk. 2010. Effect of Number Head Together on the Daily Quiz Scores and On-Task Behavior of Students with Disabilities. Journal of Behavioral Education, 19(3): 222-238

Ichsan, M. (2016). Psikologi Pendidikan Dan Ilmu Mengajar. JURNAL EDUKASI: Jurnal Bimbingan Konseling, 2(1), 60. https://doi.org/10.22373/je.v2i1.691

Jumrawarsi, J. (2017). Pengaruh Model Pembelajaran Kooperatif Tipe Find Someone Who terhadap Hasil Belajar Matematika Siswa. Jurnal Gantang, 2(2), 123-129. https://doi.org/10.31629/jg.v2i2.202

Khaeruman, Ratna Azizah, S. N. (2018). Pengaruh Multimedia Interaktif Terhadap Keterampilan Generik Sains Dan Pemahaman Konsep Elektrokimia Siswa. Jurnal Magister Administrasi Pendidikan, 2(1), 329-337.

Maheady, L dkk. 2006. The Effects of Number Head Together with and Without and Incentive Package of the Science Test Performance of a Diverse Group of Sixth Graders. Journal of Behavioral Education, 15(1): 52-65

Muhibbin Syah. (2012). Psikologi pendidikan dengan Pendekatan Baru. PT remaja Rosdakarya.

Malawati, Ratna. 2012. Analisis Kemampuan Prasyarat Maetematika Dan Hasil Belajar Fisika Siswa Pada Pembelajaran Menggunakan Model Kooperatif Tipe NHT. Unimed : Jurnal Online Pendidikan Fisika ISSN 2301-7651

Rifaldiyah, M. Y. S. W. Y. (2019). Penerapan Model Problem Based Learning terhadap Hasil Belajar Kognitif Pemecahan Masalah Matematika. TSCJ, 2(1), 19-26.

Sari, N. P. A., Kristiantari, M. G. R., \& Asri, I. G. A. A. S. (2017). Pengaruh Model Pembelajaran Literasi sebagai Budaya Sekolah terhadap Pengusaan Kompetensi Pengetahuan IPS Siswa Kelas V. E-Journal $P G S D, 5(2), 1-10$. 
Sidiq, Muhammad. 2012. Upaya Peningkatan Keaktifan Belajar Matematika Siswa Pada Pokok Bahasan Bangun Datar (SegiEmpat) Melalui Penerapan Model Participative Teaching And Learning. Skripsi. Surakarta: UMS (Tidak Diterbitkan)

Sugiyono. (2017). Statistiak untuk Penelitian. Alfabeta.

Sholikhah, Octarina Hidayatus dkk. 2014. Eksperimentasi Model Pembelajaran Kooperatif Tipe Grup Investigation (GI) dan Numbered Heads Together (NHT) pada Materi Garis Singgung Lingkaran Ditinjau dari Kecerdasan Majemuk Siswa Kelas VIII SMP Negeri Se-Kota Madiun Tahun Ajaran 2013/2014. Jurnal Elektronik Pembelajaran Matematika, 2(7): 727-739. Universitas Sebelas Maret Surakarta

Umar, W. (2012). Membangun Kemampuan Komunikasi Matematis Siswa Dalam Pembelajaran Matematika.Jurnal Ilmiah Program Studi Matematika STKIP Siliwangi Bandung, Vol 1, No.1, Februari 2012.

Putra, Erlangga dkk. 2012. Hasil Belajar Matematika dengan Pembelajaran Kooperatif Tipe Numbered Heads Together disertai LKS Berbasis Pendekatan Kontekstual. Jurnal Pendidikan Matematika, 1(1): 60-65. Universitas Negeri Padang 